\title{
Culture- Dependent Characterization of Microbes associated with Oil Palm Kernel Borer, Pachymerus cardo in the Niger Delta
}

\section{Ogbalu OK ${ }^{1 *}$ and Douglas $\mathrm{SI}^{2}$}

${ }^{1}$ Entomology Unit, Department of Animal and Environmental Biology, Rivers State University of Science and Technology, Port Harcourt, Nigeria ${ }^{2}$ Microbiology Unit, Department of Animal and Environmental Biology, Rivers State University of Science and Technology, Port Harcourt, Nigeria

\begin{abstract}
The microbes associated with the oil palm kernel were investigated. The total culturable heterotrophic bacterial, fungal and coliform counts of kernel with holes, the larvae in the kernel with holes and also the internal of the kernel were analysed using standard microbiological methods. The results of the analysis showed the following genera; Pseudomonas, Bacillus, Staphylococcus, Klebsiella, Enterobacter, Micrococcus, Aerobacter, Escherichia coli, Aspergillus niger, Aspergillus fumigatus, Aspergillus, Mucor, Rhizopus, Penicillium, Candida, Saccharomyces and Fusarium. When the bacterial and fungal counts from three locations were compared at $p \geq 0.05$, there was no significant difference in the counts. However, when the bacterial and fungal counts for each location were compared, there was significant difference at $p \geq 0.05$. Bacillus $s p$ had the highest bacterial population; this might be due to the fact that these bacteria are known soil inhabitants, endospore formers and therefore, are resistant to hash environmental conditions. This keeps them in the environment for a longer time. Aspergillus genera was the most commonly isolated fungi. Some of the organisms isolated in this study are of public health importance. Hence, there is need for proper cooking of the larvae before consumption. Since it may become a possible route of transmission of these microorganisms to man and may pose a potential health hazard especially the bacteria, while the fungi mainly to immunocompromised patients.
\end{abstract}

Keywords: Pachymerus cardo; Culture-dependent characterization; Microbes

\section{Introduction}

Pachymerus cardo (Fahraeus), a Niger Delta Palm fruit borer of the tribe Pachymerini (Coleoptera: Bruchidae: Pachymerinae) uses the Oil Palm (Elaise guineensis) as its main host plant and they are often times referred to as Palm bruchids. There are about seven known species of Pachymerus. Other genera that are in the same family with Pachymerus include Caryoborus (three species), Speciobruchus (four species) Curyobruchus (six species). Most of the aforementioned bruchids use Palms as their host plants. It was earlier reported that almost all species are south and Central American however [1] earlier reported its presence in Palm fruits of Nigeria. Bruchids have a negative impact on palms as they feed on the palm nuts and cause a reduction on the reproductive potentials of the palms. Its feeding activities wholly affect the germination of the palm seedlings. The humidity and rainfall values within sampled sites are the same with 247 days of $1200-2,700$ $\mathrm{mm}$ of rainfall and an average of $85 \%$ humidity starting from March to November [2-4]. In the sites where collections were made as in most parts of the Niger Delta, fallen seeds of the Oil Palms were observed to be attacked during the rainy seasons when percentage moisture content is high to aid the growth and development of the larvae of $P$. cardo [5] reported that $P$. cardo will not develop in kernels with moisture content below $8 \%$.

Weevils are one of the largest groups of living organisms, with more than 60,000 species feeding mostly on plants. With only one exception, their described larvae are typical plant-feeders, with mouthparts adapted to chewing plant material. Others have studied the life history of Anchylorhynchus eriospath [6], a species whose immatures feed internally on palm flowers and fruits.. Interestingly, both lineages inhabit the same hosts, raising the possibility that both intra- and inter-specific competition shaped those phenotypes. Given the scarcity of knowledge on early larval stages of concealed insect herbivores, it is possible that our findings represent an instance of a much broader phenomenon. Weevils in the genus Anchylorhynchus C. J. Schoenherr feed internally on female flowers and developing fruits of palms in the genera Syagrus Mart., Butia Becc. (Becc.) and Oenocarpus Mart. (occasionally, also in the coconut Cocos nucifera L.) [7,8]. Even though there are a few taxonomic revisions based on adults and several reports of larval feeding habits in terms of host plants $[7,9,10]$.

In an attempt to improve human protein intake by man, animal scientists are diversifying on the domestication and commercialization of non-conventional animals such as grass cutters, snails, antelopes, zebras and other mini-livestock and hexapods. Considering the environmental hazards already created by large livestock on massive scale production, the livestock industries are devising means to ameliorate the hazards by introducing alternatives to conventional animals with less production cost and provide cheaper and better animal protein supply. Thus the current trend is on the insect world [11]. Due to the simplicity of the preparation of the grub(larva), taste and texture of the meat, its flavour and nutrient content, the oil palm larva is accepted and cherished by the people of Bayelsa and Rivers states as well as other parts of the Niger Delta of Nigeria. Thus it would be of great benefit to the livestock industry that the production of the grub should be encouraged and the people of Bayelsa State enlightened on the production and consumption of the grub as meat to augment the shortage of animal protein in the diet of the people. Domestication

*Corresponding author: Ogbalu OK, Entomology Unit, Department of Animal and Environmental Biology, Rivers State University of Science and Technology, Port Harcourt, Nigeria, Tel: +234 903885 8167; E-mail: ogbaluo@yahoo.com

Received December 15, 2015; Accepted December 24, 2015; Published December 31, 2015

Citation: Ogbalu OK, Douglas SI (2016) Culture- Dependent Characterization of Microbes associated with Oil Palm Kernel Borer Pachymerus cardo in the Niger Delta. J Microb Biochem Technol 8: 014-018. doi:10.4172/1948-5948.1000255

Copyright: (c) 2016 Ogbalu OK, et al. This is an open-access article distributed under the terms of the Creative Commons Attribution License, which permits unrestricted use, distribution, and reproduction in any medium, provided the original author and source are credited. 
projects of Rhynchophorus phoenicis had been reported [12] also [13] reported on the domestication of the Niger Delta emperor moth, Bunaea alcinoe Stoll. Many reports are available on the edibility of hexapods in the Niger Delta [14,15], The workers reported on the edibility of Rhynchophorus phoenicis [14], Oryctes monoceros [14], and Gryllotalpa africana [15] and associated microbes. Previous works on the microbiological studies implicated different and similar pathogens in different edible insets within the zone of study [16,17], Also other authors $[18,19]$ reported on carcinogenic metals in Oryctes monoceros, an edible larva of the oil palms in the Niger Delta. Thus far, there is no documented evidence of any report of the Oil Palm borer, Pachymerus cardo and its associated microbes except its biogeography and distribution [20] in the Niger Delta. The aim of this study was to determine the various groups of microorganisms found on the kernel. Also, to evaluate the diversity of the microbiota of the larvae which represents the developmental stage responsible for damage to the kernel.

\section{Materials and Method}

\section{Sampling area}

Kernel with holes was picked randomly under palm trees in three different locations. The locations include; Ozuoba (1), Omoku (2) and under the palm trees close to the convocation arena within Rivers State University of Science Technology (3), Port Harcourt, all in Rivers State. These samples were collected aseptically and transported to the laboratory for analysis.

\section{Sample analysis}

Ten grams of the palm fruits were weighed and mixed with $90 \mathrm{ml}$ of physiological saline in a $250 \mathrm{ml}$ conical flask and a ten-fold serial dilution was carried out according to [21]. The kernel with holes was carefully cracked open. The larvae found in them were weighed $(1 \mathrm{~g})$ and dislodged in $9 \mathrm{ml}$ of physiological saline, which was then serially diluted. The inside of the kernel was also swabbed using sterile swab sticks. The organisms on the swab stick was also dissolved by addition of $2 \mathrm{ml}$ of saline, which was stored in the refrigerator at $4^{\circ} \mathrm{C}$ for 24 hours to ensure all the organisms are dislodged before the serial dilution [22].

\section{Statistical analysis}

Statistical analyses were performed using SPSS software. ANOVA was employed in establishing significant differences in the populations of bacteria from different locations.

\section{Microbial enumeration and isolation}

This was done using various media; nutrient agar, Sabouraud dextrose agar (SDA) and MacConkey agar and mannitol salt agar (used for the isolation Staphylococcus sp). After the ten-fold serial dilution, $0.1 \mathrm{ml}$ aliquot of each dilution was aseptically removed from the test tube dropped on the surface of the already prepared and dried agar plates mentioned herein. Flame sterilized hockey-stick was used to uniformly spread the inoculums on the agar surface. Thereafter, the inoculated plates were incubated at $37^{\circ} \mathrm{C}$ for 24 hours for bacteria. Chloramphenicol was added to the SDA used for fungal enumeration, the addition of the antibiotics prevents bacterial growth. The SDA plates were incubated at $37^{\circ} \mathrm{C}$ for 7 days. After the incubation period, plates were assessed for those having between 30 and 300 colonies which were counted and recorded. The analyses was done in duplicates, and mean values calculated, expressed as colony forming unit per gram (CFU/g).The colonies that emerged from these media were further purified by sub culturing and pure isolates stored on nutrient agar slants, preserved at $4^{\circ} \mathrm{C}$ in the refrigerator for further use $[21,22]$.

\section{Biochemical characterization of bacteria and fungi isolates}

Colonies were counted and further purified by sub-culturing. Pure cultures were analysed biochemically and morphologically identified based on the identification in the Bergey's Manual for Determinative Bacteriology [23]. For fungal identification, the microscopic examination of the isolates was carried out by needle mount method by [24]. Isolates were identified on the basis of their cultural characteristics, spores and vegetative mycelium according to [25-27].

\section{Results and Discussion}

During the study, a total of 34 bacteria were isolated which covers eight genera and 28 fungal groups covering seven genera, were isolated using various differential, selective and routine media. The results of the analysis showed the following genera; Pseudomonas, Bacillus, Staphylococcus, Klebsiella, Enterobacter, Micrococcus, Aerobacter and Escherichia coli, Aspergillus niger, Aspergillus fumigatus, Aspergillus, Mucor, Rhizopus, Penicillium, Candida, Saccharomyces and Fusarium (Tables 1-6).

Results of the investigation revealed that location 1 had the highest bacterial counts while location 2 had the least counts. Location 2 had the highest fungal counts than location 1 and 3 . When the bacterial and fungal counts from three locations were compared at $p \geq 0.05$, there was no significant difference in the counts. However, when the bacterial and fungal counts for each location were compared, there was significant difference at $\mathrm{p} \geq 0.05$. The bacterial groups isolated are members of the Gram positive and Gram negative bacteria. The kernel external had the highest microbial population and diversity, while the kernel internal had the least. The least microbial population and diversity observed in the internal of the kernel may be as a result of the larvae, spending all its developmental stage inside the kernel, feeding exclusively on the kernel tissues. This unique life style may be responsible for the low diversity of the larvae and the kernel internal.

Among the bacteria isolated, Bacillus sp (24\%) had the highest frequency of occurrence while E. coli (3\%) had the least occurrence, while for the fungal genera Aspergillus (28\%) had the highest frequency and Candida (3\%) recorded the least frequency of occurrence (Figures 1-3) [28] in their study, also observed this low population and diversity, and concluded that the microbial load and complexity of palm larvae show relatively low complexity and high similarities of organisms isolated, regardless of the site and season, which means that the microbiota pools of larvae from different host trees were similar. The microbial population on the external of the kernel ranged from $1.4 \times 10^{6}-5.7 \times$ $10^{6} \mathrm{cfu} / \mathrm{g}$, with a mean value of $3.6 \times 10^{6} \pm 124141$ for bacteria, ranged from $2.6 \times 10^{4}-3.8 \times 10^{4} \mathrm{cfu} / \mathrm{g}$, with mean value of $3.2 \times 10^{4} \pm 3464.1$ for

\begin{tabular}{|c|c|c|c|}
\hline Isolates & Location A & Location B & Location C \\
\hline Pseudomonas sp & + & + & + \\
\hline Bacillus $\mathrm{sp}$ & + & + & + \\
\hline Staphylococcus sp & + & + & + \\
\hline Klebsiella sp & + & + & + \\
\hline E. coli & + & + & - \\
\hline Enterobacter $\mathrm{sp}$ & - & - & + \\
\hline Micrococcus sp & - & - & + \\
\hline Aerobacter $\mathrm{sp}$ & + & + & - \\
\hline
\end{tabular}

+ =present, - =absent

Table 1: Bacterial isolates from kernel external. 


\begin{tabular}{|c|c|c|c|}
\hline Isolates & Location A & Location B & Location C \\
\hline Aspergillus niger & + & + & + \\
\hline Penicillium $\mathrm{sp}$ & + & + & + \\
\hline Mucor $\mathrm{sp}$ & + & + & + \\
\hline Fusarium $\mathrm{sp}$ & - & - & - \\
\hline Candida $\mathrm{sp}$ & + & - & - \\
\hline Rhizopus $\mathrm{sp}$ & + & + & + \\
\hline
\end{tabular}

Table 2: Fungal isolates from the kernel external.

\begin{tabular}{|c|c|c|c|}
\hline Isolates & Location A & Location B & Location C \\
\hline Pseudomonas sp & + & + & + \\
\hline Bacillus sp & + & + & + \\
\hline Enterbacter sp & + & - & - \\
\hline Staphylococcus sp & + & + & + \\
\hline Klebsiella sp & + & - & - \\
\hline
\end{tabular}

Table 3: Bacterial isolates found on the larvae.

\begin{tabular}{|c|c|c|c|}
\hline Isolates & Location A & Location B & Location C \\
\hline Aspergillus niger & + & + & + \\
\hline Aspergillus fumugatus & + & - & + \\
\hline Penicillium $\mathrm{sp}$ & + & + & + \\
\hline Mucor $\mathrm{sp}$ & + & + & + \\
\hline Saccharomyces $\mathrm{sp}$ & + & - & - \\
\hline
\end{tabular}

Table 4: Fungal isolates found on the larvae.

\begin{tabular}{|c|c|c|c|}
\hline Isolates & Location A & Location B & Location C \\
\hline Staphylococcus sp & + & + & + \\
\hline Bacillus $\mathrm{sp}$ & + & + & + \\
\hline Pseudomonas $\mathrm{sp}$ & + & + & + \\
\hline Enterobacter $\mathrm{sp}$ & - & + & + \\
\hline
\end{tabular}

Table 5: Bacterial isolates from kernel internal.

\begin{tabular}{|c|c|c|c|}
\hline Isolates & Location A & Location B & Location C \\
\hline Aspergillus niger & + & - & + \\
\hline Aspergillus fumigates & + & + & + \\
\hline Penicillum $\mathrm{sp}$ & + & + & + \\
\hline Mucor $\mathrm{sp}$ & - & + & + \\
\hline
\end{tabular}

Table 6: Fungi Isolated from the kernel internal.

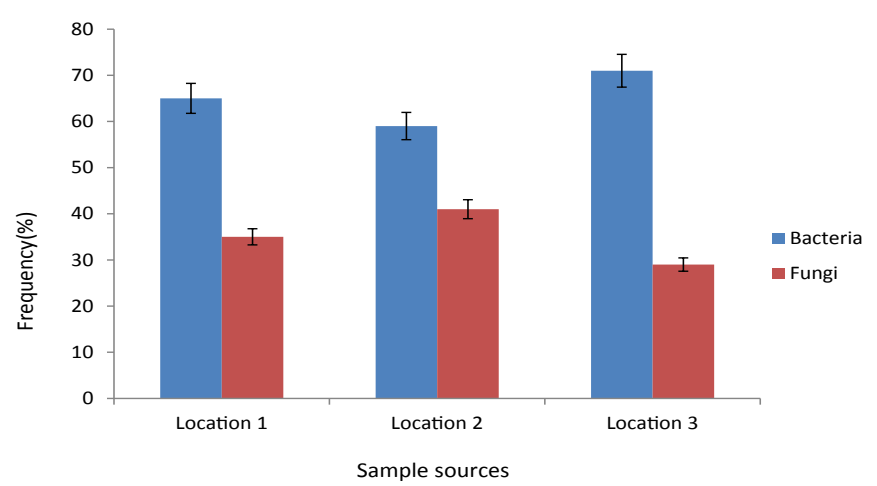

Figure 1: Frequency of occurrence of microorganisms in the sample locations.

fungi and also ranged from $3.2 \times 10^{4}-4.1 \times 10^{4} \mathrm{cfu} / \mathrm{g}$, with mean count of $3.7 \times 10^{4} \pm 2603.4$ for coliform. The microbial load for the larvae ranged from: $4.7 \times 10^{4}-9.4 \times 10^{4} \mathrm{cfu} / \mathrm{g}$ for bacteria, with a mean count of $6.3 \times 10^{4} \pm 12238.1$, ranged from $2.8 \times 10^{3}-5.2 \times 10^{3} \mathrm{cfu} / \mathrm{g}$, with a mean count of $3.3 \times 10^{3} \pm 624.5$ for fungi and ranged from $3.0 \times 10^{4}-5.2$ $\times 10^{4} \mathrm{cfu} / \mathrm{g}$, with a mean count of $2.8 \times 10^{4} \pm 1855.9$ for coliform. While the microbial load for kernel internal ranged from: $3.0 \times 10^{4}-7.2 \times 10^{4}$ $\mathrm{cfu} / \mathrm{g}$, with mean counts of $5.3 \times 10^{4} \pm 12238.37$ for bacteria, ranged from $2.1 \times 10^{3}-4.2 \times 10^{3} \mathrm{cfu} / \mathrm{g}$, with mean counts of $3.3 \times 10^{3} \pm 624.5$ for fungi and ranged from $2.4 \times 10^{4}$ to $3.0 \times 10^{4} \mathrm{cfu} / \mathrm{g}$, with mean count of $2.6 \times 10^{4} \pm 1855.9$ for coliform. The microbial populations observed in this work are similar to the observation of [14,29]. Comparing the work of [29], Acinetobacter sp and Serratia sp were not isolated from this work. [30], also isolated these organisms from a freshly milled palm oil. The presence of high population of Bacillus sp in this study may be due to the fact that these bacteria are known soil inhabitants therefore, they are resistant to hash environmental conditions.

Analysis of variance (ANOVA) was used to analyse the population of bacteria in the samples at $p \geq 0.05$, which showed there's significant difference. This was also observed in the fungi population at $p \geq 0.05$. When a comparison of the population of both the bacteria and fungi from the sampling locations was done in pairs using the least significant difference of ANOVA indicate that there is no significant difference among the locations.

The presence of some strains and species of bacteria and fungi isolated from this study, are of public health importance, especially if the larvae are eaten raw. A species of Bacillus, Bacillus cereus and a strain of Staphylococus aureus produce enterotoxin. The presence of the toxins can result in food poisoning (gastroenteritis) in individuals who consume it raw [14,31]. Staphylococcus aureus is also implicated

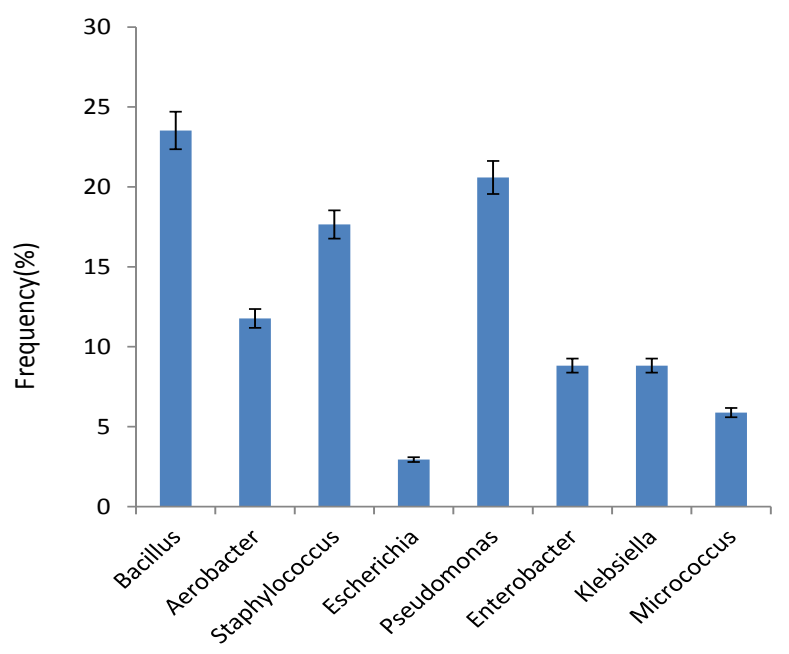

Genera of Bacteria isolated from the samples

Figure 2: Frequency of bacteria isolated from the samples.

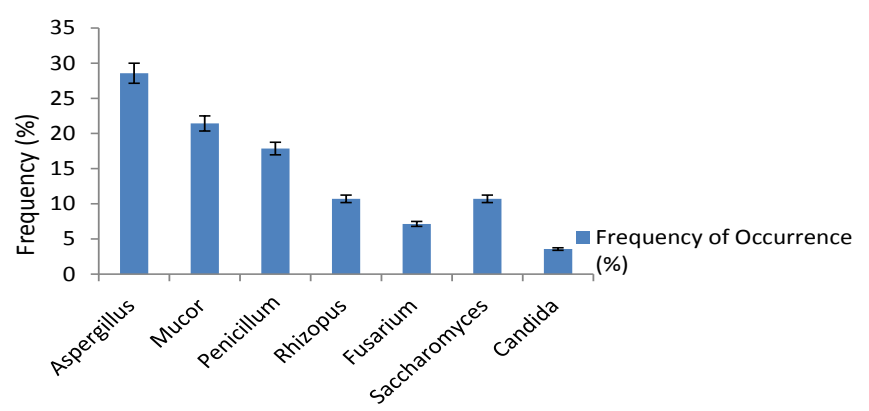

Figure 3: Frequency of fungal genera isolated from the samples. 
in wound infections. Pseudomonas sp (fluorescens) has been shown to cause spoilage of foods (especially dairy products) and fat containing foods. While $P$. aeruginosa have been implicated in urinary tract infections. Research, has also shown that Pseudomonas sp is an opportunistic pathogen, especially in immuno-compromised patients. This organism has the ability to adapt under different environmental conditions, surviving and replicating even in minimal nutritional conditions such as drinking water [32]. Enterobacter sp are found in both water and soil environment. Their presence could indicate faecal contamination. Some species are pathogenic, can cause food poisoning, involved in respiratory tract infection and sometimes cause septicaemia and meningitis [30]. The presence of E. coli and Klebsiella sp is also an indicator of faecal contamination, which may be due to defecation around the nearby bushes by farmers as their toilet. Their presence is associated with foodborne illnesses and food poisoning leading to diarrhea, fever and other health complications [31]. Fungi are noted for their ability to produce spores which help them survive even when the environmental conditions are not favourable. These fungi produce mycotoxins in food and feed products. Some members of the Aspergillus sp have been implicated in human and animal infections including superficial and local infections(cutaneous infections), infections associated with damaged tissues [aspergilloma], pulmonary infections, asthma, and clinical allergies( allergic bronchopulmonary aspergillosis] [30]. Studies has also shown that Penicillium sp produce toxins called ochratoxin-a, which is a potent nephrotoxin causing damage in pigs and other experimental animals. Aspergillus sp and Candida sp have shown outstanding infectivity in different forms of diseases ranging from mucosal to life threatening disseminated infections by activities of their fungal antigens, toxins or direct invasion of the host [33].

\section{Conclusion}

This study has shown the microbial diversity and counts associated with the palm kernel. Evaluating the microbial counts, diversity and quality especially of the larvae is necessary, since the larvae also serve as a source of food and feeds. Most of the organisms (the bacteria and fungi) isolated are normal flora and saprophytic organisms found on palm kernel and in the soil environment, therefore may just be opportunistic pathogens. However, the presence of coliforms may indicate faecal contamination, which could pose serious threat to persons as other pathogens may be present. Since the larva serves as a source of food in some locality, there is need to process them at least by cooking before consumption to prevent illnesses. It is also necessary to let the locals know the possible implication of consuming the larvae without proper cooking. This may become a possible mode of transmission of these microorganisms to man and may be a potential health hazard especially the bacteria, and the fungi mainly to immunocompromised patients.

\section{References}

1. Prevett PF (1966) The identity of the Palm Kernel Borer in Nigeria with Systematics notes on the Genus Pachymerus Thunberg [Coleoptera: Bruchidae]. Bulletin of Entomological Research 57: 181-192.

2. Adefolalu DO (1983) Rainfall pattern in the coastal areas of Nigeria. Nigeria Geog J 26: 153-170.

3. Okonkwo GI, Mbajiorgu CC (2010) Rainfall intensity-duration-frequency analysis for Southeastern Nigeria. Agric Eng Int: CIGR Journal 12: 22

4. Adejuwon JO (2011) Rainfall Seasonality in the Niger Delta Belt, Nigeria. Journal of Geography and Regional Planning 5: 51-60.

5. Rilley J, Simmons EA (1966) A Survey Of Palm Kernels Exported From Apapa and Port-Harcourt with Special Reference To Discolouration and Infestation. NSPRI Technical Report 9: 81-88.
6. Caldara R, Franz NM, Oberprieler RG (2014) Curculioninae Latreille, In Leschen RAB, Beutel, Arthropoda: Insecta: Coleoptera, beetles. 3: 589-628.

7. De Medeiros BA, Núñez-Avellaneda LA (2013) Three new species of Anchylorhynchus Schoenherr, 1836 from Colombia (Coleoptera: Curculionidae; Curculioninae; Acalyptini). Zootaxa 3636: 394-400.

8. Roberta De Melo V, Bruno Augusto Souza de M (2013) A new species of Anchylorhynchus Schoenherr (Coleoptera: Curculionidae) from the Amazon, with a record of a new host palm for the genus. Zootaxa 3709: 394-400.

9. Silberbauer-Gottsbeger I, Vanin SA, Gottsbeger G (2013) Morphological and functional flower characteristics of New and Old World Annonaceae with respect to their mode of pollination. Taxon 52: 701-718.

10. Oberprieler RG, Marvaldi AE, Anderson RS (2007) Weevils, weevils, weevils everywhere. Zootaxa 520: 5326.

11. FAO (2012) The State of Food Insecurity in the World. 31-51.

12. Thomas CN, Ogbalu OK, Okwakpam BA (2004) Oviposition of Rhynchophorus phoenicis in Palms of Niger Delta. Indian Journal of Agric Research 38: 126130

13. Ogbalu OK, Manuel RB, Chukwu M (2016) Carcinogenic metals in edible beetle, [Oryctes monoceros] of the Niger Delta.

14. Ogbalu OK, Williams JO (2015) The edibility, Methods of Preparation of the Raphia Palm Beetle Rhyncophorus phoenicis (Coleoptera: Curculionidae) in the Niger Delta and Associated Microorganisms. IOSR Journal of Pharmacy and Biological Sciences 10: 125-129.

15. Ogbalu OK, Renner NR (2015) Microbiological Investigations on Gryllotalpa africana [Orthoptera: Gryllotalpidae], an Edible Cricket of the Niger Delta. Journal of Pharmacy and Biological Sciences 10: 38-42.

16. Braide W, Nwaoguikpe RN (2011) Assessment of microbiological quality and nutritional values of a processed edible weevil caterpillar (Rhynchophorus phoenicis) in Port Harcourt, Southern Nigeria. Intl J Biol Chem Sci 5: 410-418.

17. Braide W, Oranusi S, Udegbunam LI, Oguoma O, Akobondu C, et al. (2011) Microbiological quality of an edible caterpillar of an edible caterpillar of an Emperor Moth, Bunaea alcinoe. Journal of Ecology and the Natural Environment 3: 176-180.

18. Ogbalu OK, Bob RB (2016) Heavy metals in Bunaea alcinoe Stoll [Lepidoptera: Saturnidae], an edible moth of the Niger Delta.

19. Chukwu M (2005) some aspects of the Biology of the Oil Palm Weevil 224

20. Onwuteaka JN, Ogbalu OK (2015) GIS based infestation biogeography of palm weevils, Pachymerus cardo in the Niger Delta, Nigeria. Journal of Environment and Earth Science 5: 150-162.

21. Harrigan WF, McCance ME (1990) Laboratory Methods in Food and Diary Microbiology, Academic Press, London.

22. Chikere CB, Azubuike CC (2014) Culture dependent Characterization of in Biofilms from selected Microhabitats in Rivers State, Nigeria. African Journal of Microbiology Research 8: 1922-1930.

23. Holt JG, Kreig NR (1994) Bergey's Manual of Determinative Bacteriology Baltimore, William and Wilkins, USA.

24. Cheesebrough M (2000) District Laboratory Practice in Tropical Countries, Cambridge University Press, London.

25. Barnett HL, Hunter BB (1972) Illustration of Genera of Fungi Imperfecti, 3rd edition, Burgess Publication Co Minneapolis.

26. Larone, DH (1995) Medically important fungi: a guide to identification, ASM Press, Washington DC.

27. Doggett MS (2000) Characterization of fungal biofilms within a municipal water distribution system. Appl Environ Microbiol 66: 1249-1251.

28. Tagliavia M, Messina E, Manachini B, Cappello S, Quatrini P (2014) The gut microbiota of larvae of Rhynchophorus ferrugineus Oliver (Coleoptera: Curculionidae). BMC Microbiol 14: 136.

29. Amadi EN, Kiin DB, Kpormon LB (2014) Microbial flora and Nutritional composition of adult palm wine Beetle. Int'I Journal of Current Microbiology and Applied Science 3: 189-192.

30. Okogbenin OB, Okogbenin EA, Okunwaye T, Odigie (2014) Isolation of food pathogens from freshly milled palm oil and the effect of sterilization on oil quality parameters. Journal of Food Security 2: 65-71. 
Citation: Ogbalu OK, Douglas SI (2016) Culture- Dependent Characterization of Microbes associated with Oil Palm Kernel Borer, Pachymerus cardo in the Niger Delta. J Microb Biochem Technol 8: 014-018. doi:10.4172/1948-5948.1000255

31. Ogbalu OK (2015) Microbiological Investigation of Selected Flies of Public Health Importance from a Waste Dump Site in Port Harcourt, Nigeria. IOSR Journal of Pharmacy and Biological Sciences 10: 75-78.

32. Okechalu JN, Dashen MM, Lari PM (2011) Microbiological quality and chemical characteristics of palm oil sold within Jos Metropolis, Plateau State, Nigeria. Journal of Microbiol Biotech Res 1: 107-112.

33. Das BS (2013) Burden of Candida spp. and Aspergillus spp. in pond water in and around South Kolkata. Int Journal of Current Microbiol and applied Sci 2 : 256-260. 